NBER WORKING PAPER SERIES

\title{
IS-LM-BP IN THE PAMPAS
}

Luis Felipe Céspedes

Roberto Chang

Andrés Velasco

Working Paper 9337

http://www.nber.org/papers/w9337

\section{NATIONAL BUREAU OF ECONOMIC RESEARCH \\ 1050 Massachusetts Avenue \\ Cambridge, MA 02138 \\ November 2002}

We are grateful to seminar participants at Harvard University, the Middle Eastern Technical Institute (Ankara), Universidad Torcuato di Tella (Buenos Aires) and Universidad de Chile (Santiago) for comments, and to the Harvard Center for International Development for financial support. The title is borrowed from Taylor (1981). The views expressed herein are those of the authors and not necessarily those of the National Bureau of Economic Research.

(C) 2002 by Luis Felipe Céspedes, Roberto Chang and Andrés Velasco. All rights reserved. Short sections of text, not to exceed two paragraphs, may be quoted without explicit permission provided that full credit, including (C) notice, is given to the source. 
IS-LM-BP in the Pampas

Luis Felipe Céspedes, Roberto Chang and Andrés Velasco

NBER Working Paper No. 9337

November 2002

JEL No. E0, F0

\section{ABSTRACT}

Emerging markets (sometimes endowed with fertile pampas) have limited access to world capital markets and suffer from original sin: they cannot borrow in their own currency. Does this mean that monetary and exchange rate policy has non-standard effects in such countries? We develop a simple ISLM-BP model with balance sheet effects to study that question. Our answer: it all depends.

Luis Felipe Céspedes

International Monetary Fund

700 19th Street, NW

Washington, DC 20431

lcespedes@imf.org
Roberto Chang

Rutgers University

Department of Economics

New Brunswick, NJ 08901

chang@economics.rutgers.edu
Andres Velasco

Kennedy School of Government

79 JFK Street

Littauer 106

Cambridge, MA 02138

and NBER

andres_velasco@harvard.edu 


\section{Introduction}

Most standard macro models of the open economy, such as the textbook IS-LMBP model, treat financial markets and international capital mobility as perfect. In that world, only expectations of future returns, properly arbitraged, guide capital flows and investment; corporate balance sheets and current output levels are irrelevant.

There are many reasons to be doubtful about this approach. Much recent research provides reasons to believe that sovereign risk, limited and costly monitoring, and imperfect contract enforceability, render international capital markets particularly prone to failure, in the sense that agents cannot borrow all they want at the world rate of interest, limited only by intertemporal solvency constraints. The problem is compounded by original sin, which prevents almost all emerging countries from borrowing in their own currencies. This leaves them exposed to currency and relative price risk, making repayment even dicier.

Policy makers fret a great deal over the potentially harmful balance sheet effects of devaluation. They were the main reason why Argentina delayed changes in its peg -despite massive overvaluation and a deepening recession- until the economy collapsed along with the currency board. Similar concerns have been voiced 
in Uruguay and in less-dollarized Brazil. Allegedly, IS-LM-BP works differently in the pampas of these three countries, and in others like them.

We have developed several models of the open economy that embed financial market imperfections in otherwise standard optimizing dynamic models. Here we present a particularly simple one, a variant of the textbook IS-LM-BP model. Though it has a simple graphical representation, this model permits us to pose a richer array of questions, and obtain more nuanced answers, than does the traditional perfect-capital-mobility approach. In fact, the standard model is simply a special case of our more general framework.

Capital market imperfections and balance sheet effects matter in two senses. First, they magnify the domestic real effects of adverse external shocks, such as a fall in export volumes or an increase in the world real interest rate. Second, devaluation may be expansionary (as in the standard model) or contractionary. The second result requires particularly strong balance sheet effects, arising from both high sensitivity of risk premia and large inherited dollar debts. Then, and only then, does IS-LM-BP turn out to operate differently in the pampas. 


\section{The Model}

Monopolistically competitive firms in the home economy produce differentiated goods using labor and capital. These goods are exported or sold to domestic agents. There is also a foreign good, which can be imported. Capital is made up of the domestic and foreign goods, with Cobb-Douglas shares $\gamma$ and $1-\gamma$, and depreciates fully after one period. Prices and wages are pre-set for one period, but free to adjust thereafter.

Labor and capital are supplied by distinct agents called workers and entrepreneurs. Workers work and consume an aggregate of the domestic and foreign good. ${ }^{1}$ Entrepreneurs own capital, and also own the firms. In order to finance investment in excess of their own net worth, entrepreneurs borrow from the world capital market. As in Bernanke and Gertler (1989), the cost of borrowing depends inversely on net worth relative to the amount borrowed.

In what follows all variables are in percentage deviation from the no-shock steady state. ${ }^{2}$ Start with the IS, which is standard:

$$
y=\alpha_{i} i+\alpha_{x} x+\alpha_{e} e
$$

\footnotetext{
${ }^{1}$ With Cobb-Douglas shares $\gamma$ and $1-\gamma$.

${ }^{2}$ Except for the world interest rate and the risk premium, which are just deviations (not percentage deviations) from the steady state.
} 
where $y$ is output of the domestically produced good, $i$ is investment, $x$ is the dollar value of exports and $e$ is the real exchange rate (the value of the foreign goods in terms of the domestic good), The $\alpha$ 's are positive coefficients, which in turn are combinations of the underlying preference and technology parameters of the model (see the appendix for details). Under our assumptions, $x$ is exogenously given, while $e$ is endogenous (or at least influenced by monetary policy when prices are sticky). For a given $e$, the IS schedule slopes up in $(i, y)$ space.

Consider next the LM, which can be written as

$$
m=\beta_{y} y+\beta_{e} e-\beta_{i} i
$$

where $m$ is the value of money in terms of the domestic good, $\beta_{y}$ and $\beta_{i}$ are positive coefficients (all functions of underlying structural parameters), and $\beta_{e}$ may be positive or negative depending on whether the elasticity of money demand with respect to consumption expenditures is larger or smaller than one. ${ }^{3}$ The real exchange rate enters money demand because it is the value of monetary balances in terms of consumption that matters to the agents who hold it, and they consume both the foreign and the domestic good. Hence, a change in relative prices (a move

\footnotetext{
${ }^{3}$ If this elasticity is smaller than one, then $\beta_{e}$ is positive, and viceversa. If it is exactly one, then $\beta_{e}=0$.
} 
in $e$ ) alters the home good value of consumption, and changes money demand as well. The reason why money demand falls with investment is as follows: Holding other factors constant, money demand today depends inversely on consumption tomorrow (recall the standard Euler relationship), and consumption tomorrow is increasing in investment today.

Turn next to the BP. It contains the non-standard features of the model, so we derive it in more detail. Begin with the investment demand equation

$$
i=-(\rho+\eta)+\gamma e
$$

where $\rho$ is the world rate of interest and $\eta$ the country risk premium (both in units of the foreign good). This relationship can easily be derived from the standard rate of return international arbitrage equation (see the appendix for details). As it stands, it has a simple intuition: investment is decreasing in the relevant international cost of capital (recall entrepreneurs borrow abroad to finance investment) and increasing in the current real exchange rate-because, ceteris paribus, a higher $e$ today means a lower expected real depreciation between today and tomorrow, and hence a lower cost of foreign capital, when measured in terms of the domestic good. 
Crucially, the risk premium is endogenously determined and given by

$$
\eta=\mu[(1-\gamma) e+i-n]
$$

where $n$ is entrepreneurs' net worth (in units of the domestic good) and $\mu$ is a positive coefficient. Intuitively, the risk premium increases when the value of current investment is high (we can think of $(1-\gamma) e$ as the price of the investment good in terms of the home good) and decreases with net worth. For a derivation of this relationship from an underlying contract environment with imperfect information and costly monitoring, see Céspedes, Chang and Velasco (2001). Notice that capital markets are perfect if $\mu=0$.

Finally, net worth is given by

$$
n=\delta_{y} y-\delta_{e} e
$$

where both $\delta$ 's are positive coefficients that increase with the initial stock of dollar liabilities relative to initial net worth. An increase in output raises the income of capitalists and therefore increases net worth. A depreciation of the (real) exchange rate increases the output value of debt repayments, because of dollarization of liabilities, and reduces net worth. 
Substituting 2.5 into 2.4 we have

$$
\eta=\mu\left[\left(1-\gamma+\delta_{e}\right) e+i-\delta_{y} y\right]
$$

so that the risk premium unambiguously increases with $e$ and $i$ and decreases with $y$. Finally, substituting this into 2.3 we arrive at the BP curve:

$$
i=-\left(\frac{1}{1+\mu}\right) \rho+\left(\frac{\mu \delta_{y}}{1+\mu}\right) y+\left[\frac{\gamma-\mu\left(1-\gamma+\delta_{e}\right)}{1+\mu}\right] e
$$

Quite naturally, investment is decreasing in the world rate of interest. The other two terms are more novel. Investment increases with output only if capital markets are imperfect $(\mu>0)$, since higher output increases net worth and reduces the risk premium. Hence the BP curve slopes up in $(i, y)$ space for a given real exchange rate and shock to the world interest rate. If $\mu=0$, the $\mathrm{BP}$ is horizontal.

Notice also that investment may be increasing or decreasing in the real exchange rate. Standard arbitrage forces described above push for an increasing relationship: a higher $e$ makes borrowing abroad cheaper. But the balance sheet effect pushes in the opposite direction: a higher $e$ means a higher value of debt payments, and hence lower net worth and higher risk premia. Notice the balance 
sheet effect prevails when capital market imperfections are high (large $\mu$ ) and when the initial stock of dollar debt is high (large $\delta_{e}$ ). If the coefficient on $e$ is positive, we have a financially vulnerable economy. If the coefficient is negative, we have a financially robust economy. The size of balance sheets effects also matter for the slope of the BP curve. The stronger the balance sheet effects (the larger are $\mu$ and $\delta_{y}$ ), the larger the slope of the BP curve.

We solve the model diagrammatically under the regime of fixed (but adjustable) exchange rates. Because the home currency price is predetermined, a fixed nominal exchange rate makes the relative price $e$ also predetermined. For a given $e$, the intersection of the IS and $\mathrm{BP}$ curves pins down investment and output. ${ }^{4}$ In turn, the LM yields the level of the money supply necessary for that particular equilibrium to obtain. ${ }^{5}$

\footnotetext{
${ }^{4}$ We consider only the case in which the slope of the IS is larger that the slope of the BP. The opposite case is empirically odd, since it implies that an increase in the world interest rate or a fall in exports leads the economy to a boom in production and investment.

${ }^{5}$ Recall these are percentage deviations from the no-shock steady state, holding prices and wages constant. Without nominal stickiness, ouput is exogenous (pinned down by the inherited capital stock and by equilibrim labor supply $l=0$ ), the IS and BP pin down the equilibrium real exchange rate for a given output level, and the LM only determines the price level.
} 


\section{Effects of external and policy shocks}

Consider first the effects of a fall in current exports, depicted in figure 1. The shock shifts the IS up and to the left, so that for each level of investment there is now a smaller corresponding output level. The new intersection is at point A, with lower investment and output than in the steady state. The output fall is as in the standard model with perfect capital markets and no balance sheet effects, but the fall in investment is not. In that model, a fall in exports today does not affect the profitability of capital tomorrow, and hence it leaves investment unchanged. That is what happens in our model in the special case $\mu=0$, so that the BP curve is horizontal. Notice that with stronger balance sheet effects (larger $\mu$ and $\delta_{y}$ ) the BP becomes steeper, and magnifying the adverse effects on both investment and output.

Consider next the effects of a one-period increase in the world rate of interest. In figure 2, the shock shifts the $\mathrm{BP}$ down and to the right, so that investment is lower for each output level. The result is lower investment and output, as in point A. This is qualitatively as it would be in the standard model with perfect capital markets and a horizontal BP curve, but quantitatively there is a difference: for the same downward shift, the steeper the $\mathrm{BP}$ the larger the reduction in investment 
and output. The capital market imperfections and resulting balance sheet effects magnifies the real effects of adverse interest rate shocks. ${ }^{6}$

Can monetary policy play a countercyclical role? To answer that question we look at the impact of a real depreciation, accommodated by monetary policy. Start with a financially robust economy. This is the case in which initial dollar debt is low with respect to net worth and the elasticity of the risk premium with respect to the ratio of investment spending to net worth is also low. A depreciation of the real exchange rate shifts the IS down and the BP up. This situation appears in figure 3. Both output and investment unambiguously go up. This is just as in the standard model: real depreciation is expansionary, and it can be used to offset the real effects of adverse shocks. ${ }^{7}$

Turn next to the financially vulnerable economy. This is the case in which balance sheets effects are strong, i.e., the initial level of debt is high and the elasticity $\mu$ is also high. Figure 4 illustrates the three possible situations. The IS still shifts down, but now the BP shifts down as well. The economy may settle in a point like A with higher output and investment (this is an economy that is

\footnotetext{
${ }^{6}$ The same is true of export shocks.

${ }^{7}$ Notice that the presence of financial imperfections has ambiguous effects on the size of the expansion. On the one hand, having $\mu>0$ and $\delta_{e}$ large reduces the size of the vertical shift in the $\mathrm{BP}$; on the other hand, a large $\mu$ increases the slope of the BP, which magnifies the equilibrium impact of any depreciation.
} 
vulnerable but not too much so); a point like $\mathrm{B}$ where there is a trade-off between investment and output; and a case like $\mathrm{C}$ where both output and investment decline. The last one is the case of unambiguously contractionary devaluation, and trying to use exchange rate and monetary policy for counter-cyclical purposes can only make matters worse.

The intuition of why devaluation can be contractionary is simple: with imperfect capital markets, balance sheets matter; if there are enough inherited dollar liabilities, the real depreciation worsens the balance sheet and increases the risk premium; in turn, this pulls down investment and aggregate demand; if the standard demand-switching effects of devaluation are not sufficiently strong, the overall impact can be contractionary.

Again, notice that none of this could happen with perfect capital markets. In that case the $\mathrm{BP}$ is horizontal and shifts up after a real devaluation. The only possible outcome is an increase in both investment and output.

\section{Conclusions}

The analysis suggests that the currently fashionable conclusion that liability dollarization renders monetary policy useless, and fully justifies "fear of floating," is much too simple. When balance sheet effects are not too strong, the model 
behaves qualitatively just like the standard one, though quantitatively the capital market imperfections magnify the effects of adverse external shocks. In that case, monetary and exchange rate policy have the same effects as in the textbook example.

With very imperfect international financial markets and large inherited dollar debts, matters are different. An unexpected real devaluation can depress both investment and output, justifying policymakers' fears. The task ahead is to sort out when and how these circumstances arise. In previous work we have found that it takes unrealistically high steady state debt ratios and risk premia to generate the contractionary case, but researchers using more disaggregated models and alternative distributions for shocks may come to different conclusions. ${ }^{8}$ Putting imperfect credibility into the picture is also important: it is in short supply in the pampas, and it crucially affects the beneficial results of devaluation. Again, in a previous paper we found that imperfect credibility, even in the presence of balance sheet effects, does not overturn received wisdom on the desirability of flexible exchange rates and countercyclical monetary policy. ${ }^{9}$ But the issue surely remains open.

\footnotetext{
${ }^{8}$ See Céspedes, Chang and Velasco (2001).

${ }^{9}$ See Céspedes, Chang and Velasco (2002).
} 


\section{A. Appendix}

For simplicity we assume only two periods, $t=0,1$, and focus on the effect of shocks only at the start of period 0 .

\section{A.1. Domestic Production}

Production of each variety of domestic goods is carried out by a continuum of firms acting as monopolistic competitors. These firms have access to a Cobb-Douglas technology given by

$$
Y_{j t}=A K_{j t}^{\alpha} L_{j t}^{1-\alpha}, 0<\alpha<1
$$

where $Y_{j t}$ denotes output of variety $j$ in period $t, K_{j t}$ denotes capital input and $L_{j t}$ denotes labor input. Assume that workers' labor services are heterogeneous. The input $L_{j t}$ is a CES aggregate of the services of the different workers in the economy:

$$
L_{j t}=\left[\int_{0}^{1} L_{i j t}^{\frac{\sigma-1}{\sigma}} d i\right]^{\frac{\sigma}{\sigma-1}}
$$

where workers are indexed by $i$ in the unit interval, $L_{i j t}$ denotes the services purchased from worker $i$ by firm $j$, and $\sigma>1$ is the elasticity of substitution 
among different labor types. The minimum cost of a unit of $L_{t}$ is given by

$$
W_{t}=\left[\int_{0}^{1} W_{i t}^{1-\sigma} d i\right]^{\frac{1}{1-\sigma}}
$$

which can be taken to be the aggregate nominal wage. The $j^{\text {th }}$ firm's maximizes expected profits in every period. Profits are given by

$$
\Pi_{j t}=P_{j t} Y_{j t}-\int_{0}^{1} W_{i j t} L_{i j t} d i-R_{t} K_{j t}
$$

where $R_{t}$ is the return to capital, and profits are expressed in terms of the domestic currency (henceforth called peso), subject to the production function in A.1 and the demand for its good

$$
Y_{j t}^{d}=\left[\frac{P_{j t}}{P_{t}}\right]^{-\theta} Y_{t}^{d}
$$

where $Y_{t}^{d}$ must be understood to include demand from domestic consumers and investors and foreign consumers. Cost minimization yields the demand for worker $i^{\prime}$ s labor:

$$
L_{i j t}=\left(\frac{W_{i t}}{W_{t}}\right)^{-\sigma} L_{j t}
$$


where

$$
L_{j t}=\frac{\int_{0}^{1} W_{i j t} L_{i j t} d i}{W_{t}}
$$

Cost minimization also requires

$$
\frac{R_{t} K_{t}}{W_{t} L_{t}}=\frac{\alpha}{1-\alpha}
$$

Finally, firms will set prices for its differentiated product as a constant markup over marginal cost. In the symmetric monopolistic competitive equilibrium, prices are set such that

$$
E_{t-1}\left\{\frac{W_{t} L_{t}}{P_{t} Y_{t}}\right\}=(1-\alpha)\left(\frac{\theta-1}{\theta}\right)
$$

\section{A.2. Workers}

There is a continuum of workers, whose total "number" is normalized to one. The representative worker has preferences over consumption, labor supply, and real money balances in each period $t$ given by

$$
\log C_{t}-\left(\frac{\sigma-1}{\sigma}\right) \frac{1}{v} L_{t}^{v}+\frac{1}{1-\varepsilon}\left(\frac{M_{t}}{Q_{t}}\right)^{1-\varepsilon}
$$


where $v>1$ and $\varepsilon>0$. The consumption quantity $C_{t}$ is an aggregate of home and imported goods:

$$
C_{t}=\kappa\left(C_{t}^{H}\right)^{\gamma}\left(C_{t}^{F}\right)^{1-\gamma}
$$

where $C_{t}^{H}$ denotes purchases of a basket of the different varieties of goods produced domestically, $C_{t}^{F}$ purchases of the imported good, and $\kappa=\left[\gamma^{\gamma}(1-\gamma)^{1-\gamma}\right]^{-1}$ is an irrelevant constant. Assume that domestically produced goods are aggregated through a C.E.S. function represented by

$$
C_{t}^{H}=\left[\int_{0}^{1} C_{j t}^{\frac{\theta-1}{\theta}} d j\right]^{\frac{\theta}{\theta-1}}, \theta>1
$$

Assume also that the imported good has a fixed price, normalized to one, in terms of a foreign currency, which we shall refer to as the dollar. Also, we assume that imports are freely traded and that the Law of One Price holds, so that the peso price of imports is equal to the nominal exchange rate of $S_{t}$ pesos per dollar.

Assume also that the only asset that workers can hold is money. Then, in every period $t$, the $i^{\text {th }}$ workers' choices are constrained by

$$
Q_{t} C_{i t}=P_{t} C_{i t}^{H}+S_{t} C_{i t}^{F}=W_{i t} L_{i t}+T_{t}-M_{i t}+M_{i t-1}
$$


where $P_{t}$ is the peso price of one unit of the basket of domestically produced goods, given by

$$
P_{t}=\left[\int_{0}^{1} P_{j t}{ }^{1-\theta} d j\right]^{\frac{1}{1-\theta}},
$$

and $Q_{t}$ is the minimum cost of one unit of aggregate consumption, or CPI index:

$$
Q_{t}=P_{t}^{\gamma} S_{t}^{1-\gamma}
$$

Fiscal policy is as simple as can be: inflation tax revenues are rebated to workers through lump sum transfers. Then,

$$
M_{t}-M_{t-1}=T_{t}
$$

where $M_{t}=\int_{0}^{1} M_{i t} d i$. This assumption ensures that, in the symmetric equilibrium, workers consume their nominal income:

$$
Q_{t} C_{t}=W_{t} L_{t}
$$

Now, purchasing consumption at minimum cost requires 


$$
\left(\frac{1-\gamma}{\gamma}\right) \frac{C_{t}^{H}}{C_{t}^{F}}=\frac{S_{t}}{P_{t}} \equiv E_{t}
$$

where absence of the subscript $i$ indicates that we have imposed symmetry in equilibrium. Additionally, we have defined $E_{t}$ as the price of foreign goods in terms of domestic goods, or the real exchange rate.

Each worker will optimally supply labor to equate his marginal disutility of labor to its marginal return. Our assumptions on preferences then ensure that

$$
{ }_{t-1} L_{t}^{v}=1
$$

in equilibrium.

Now adopt the convention that no subscript indicates an initial period variable, while a subscript 1 indicates a final period variable. Money demands in periods 0 and 1 are given by

$$
\begin{gathered}
\left(\frac{M}{Q}\right)^{-\varepsilon}+\beta \frac{1}{C_{1}} \frac{Q}{Q_{1}}=\frac{1}{C} \\
\left(\frac{M_{1}}{Q_{1}}\right)^{-\varepsilon}=\frac{1}{C_{1}}
\end{gathered}
$$




\section{A.3. Entrepreneurs}

Entrepreneurs borrow from abroad in order to finance investment. They do it using dollar denominated debt contracts which, due to imperfections in the financial markets, require paying a risk premium over the risk free interest rate. Assume that entrepreneurs start with some inhered debt repayments, due at the end of the period, equal to $D$ in dollars. They also they own a quantity $K$ of capital which is used to produce the home good in period 0. After debt repayments, these entrepreneurs borrow from the world capital market in order to finance investment in excess of their own net worth.

Investment becomes capital next period and is produced by combining home goods and imports. For simplicity, we assume that capital is produced in the same

fashion as in A.11. Therefore, the cost of producing one unit of capital available in period 1 is $Q$. The entrepreneurs' budget constraint in period 0 is

$$
P N+S D_{1}=Q I
$$

where $N$ represents net worth, $D_{1}$ denotes the amount borrowed abroad in period 0 and $I=K_{1}$ investment in period 1 capital.

Net worth plays a crucial role because the interest cost of borrowing abroad is 
not simply the world safe rate $\rho$. Entrepreneurs borrow abroad paying a premium, $\eta$, above this risk free interest rate. We assume that the risk premium is an increasing function in the ratio of the value of investment to net worth as in Bernanke and Gertler (1989). In particular, we assume the following functional form for this relation

$$
1+\eta=\left(\frac{Q I}{P N}\right)^{\mu}
$$

We assume that capital depreciates completely in production. In equilibrium, the expected yield on capital in dollars must equal the cost of foreign borrowing

$$
\frac{R_{1}}{Q}=(1+\rho)(1+\eta)\left(\frac{S_{1}}{S}\right)
$$

Given that entrepreneurs own local firms, the income that they receive is not only the payment to capital. They also receive the profits associated to the monopolistic power that each firm has. Entrepreneurs' net worth is

$$
P N=R K+\Pi-S D=P Y-W L-S D
$$


where $\Pi$ reflects profits from the firms in pesos.

\section{A.4. Equilibrium}

Market clearing for the home goods require that domestic output be equal to demand. In period 0 , the market for home goods will clear when

$$
Y=\gamma\left(\frac{Q}{P}\right)(I+C)+E X
$$

Notice the term $E X$ stands for the home good value of exports to the rest of the world, where $X$ is exogenous. ${ }^{10}$

Given that period 1 is the final period, there is no investment on it. Assuming that entrepreneurs consume only foreign goods, the market clearing condition for the second period is

$$
P_{1} Y_{1}=\gamma Q_{1} C_{1}+E_{1} P_{1} X_{1}
$$

This last equation can be simplified further, since workers consume all their income each period:

\footnotetext{
${ }^{10}$ This is similar to Krugman (1999), and can be justified by positing that the foreign elasticity of substitution across goods in consumption is one, and that the share of domestic goods in foreigners' expenditure is negligible. This last fact allows us to treat $X$ as exogenous.
} 


$$
Y_{1}=\tau E_{1} X_{1}
$$

where $\tau=\left[1-\gamma(1-\alpha)\left(1-\theta^{-1}\right)\right]^{-1}>1$

\section{A.5. Linearization}

The next step consists in obtaining log-linear approximations around the equilibrium with no shocks. Start by noticing that A.15 implies

$$
q_{t}-p_{t}=(1-\gamma)\left(s_{t}-p_{t}\right)=(1-\gamma) e_{t}
$$

in both periods. Next derive equilibrium relations in period 1. The first relation is the log-linear version of equation A.17

$$
q_{1}+c_{1}=w_{1}+l_{1}
$$

Equation A.9 shows that wage income in period 1 is a fraction of the total revenue.

Therefore,

$$
p_{1}+y_{1}=w_{1}+l_{1}
$$


Combining these last three equations we obtain that

$$
c_{1}=y_{1}-\left(q_{1}-p_{1}\right)=y_{1}-(1-\gamma) e_{1}
$$

Assuming no export shocks in period 1, the log-linear version of the market clearing condition for period 1 is

$$
y_{1}=e_{1}
$$

Using these two equations together we obtain $c_{1}=\gamma e_{1}$. Now, since under no shocks labor supply is fixed at one (recall the first order condition for labor supply), we have $y_{1}=\alpha i$. Combining this with A.33 we have

$$
\alpha i=e_{1}
$$

Pulling together these results we arrive at

$$
c_{1}=\gamma \alpha i
$$

We can now solve the model in the initial period. The log-linear version of the resource constraint in period 0 is 


$$
\tau y+(1-\tau)(q+c)=\lambda(q+i)+(1-\lambda)(e+x)
$$

where $\lambda=\frac{\bar{Q} \bar{I}}{\bar{Q} \bar{I}+\bar{E} \bar{X}}<1$ and where, without loss of generality, we have set $p=0$.

Given that capital is a pre-determined variable in period 0 , deviations of output from its no-shock equilibrium will be matched by changes in labor only:

$$
y=(1-\alpha) l
$$

Log-linearizing equation A.17 we have

$$
q+c=l,
$$

since the nominal wage is pre-set. Combining these last two equations we have that

$$
q+c=\frac{y}{1-\alpha}
$$

Replacing this last relation and A.29 into A.36 and reordering we obtain the IS curve 


$$
y=\tau\left[1-\gamma\left(1-\theta^{-1}\right)\right]^{-1}[\lambda i+(1-\gamma \lambda) e+(1-\lambda) x]
$$

which is equation 2.1 in the text.

Now focus on the money market. Log-linearize money demand in each period, given by equations A.20 and A.21, which yields

$$
\begin{gathered}
\varepsilon\left(m_{1}-q_{1}\right)=c_{1} \\
\varepsilon \omega(m-q)+(1-\omega)\left(c_{1}+q_{1}-q\right)=c
\end{gathered}
$$

where $\omega=1-\beta \frac{\bar{Q} \bar{C}}{Q_{1} \bar{C}_{1}}$. Note that $\omega$ is between 0 and 1 as long as the growth of nominal consumption is not too negative, which we assume from now on. Notice that $\varepsilon^{-1}$ can be interpreted as the elasticity of money demand with respect to consumption expenditures. Using A.35 and A.39 to substitute out the consumptions, and rearranging, we have the LM schedule:

$$
m=\frac{y}{\varepsilon \omega(1-\alpha)}-\left(\varepsilon^{-1}-1\right)(1-\gamma) e-\left(\omega^{-1}-1\right) \varepsilon^{-1} \alpha i
$$

which is equation 2.2 in the text. 
The final block of equations to be solved is the one associated with the entrepreneurs. The log-linear version of the arbitrage relation (equation A.24) is

$$
\left(r_{1}-p_{1}\right)-q=\rho+\eta+e_{1}-s
$$

while the $\log$-linear version of A.8 is $r_{1}-p_{1}=-i(1-\alpha)$. Using this, A.29 and A.34 we have

$$
i=-(\rho+\eta)+\gamma e
$$

which is 2.3 in the text. The log-linear version of the equation for the risk premium (A.23) is

$$
\eta=\mu(q+i-n)
$$

which, using A.29, is 2.4 in the text. The log-linear version of net worth equation (A.25) is

$$
n=\theta^{-1}\left[1-(1-\alpha)\left(1-\theta^{-1}\right)\right]^{-1}(1+\psi) y-\psi e
$$

where $\psi=\frac{\overline{E D}}{\bar{N}}>0$. This is 2.5 in the text. Note that when $\psi$ is large, initial debt is also large relative to net worth. 


\section{References}

[1] Bernanke, B. and M. Gertler, "Agency costs, Net worth, and Business Fluctuations," American Economic Review 79, 1989, pp. 14-31.

[2] Céspedes, L., R. Chang and A. Velasco, "Balance Sheets and Exchange Rate Policy," NBER Working Paper No. , 2001.

[3] Céspedes, L., R. Chang and A. Velasco, "Dollarization of Liabilities, Net Worth Effects and Optimal Monetary Policy." Forthcoming in Preventing Crises in Emerging Markets, J. Frankel and S. Edwards (eds.), University of Chicago Press, 2002.

[4] Krugman, P. "Balance Sheets, the Transfer Problem and Financial Crises," in International Finance and Financial Crises, P. Isard, A. Razin and A. Rose (eds.), Kluwer Academic Publishers, 1999.

[5] Taylor, L. "IS/LM in the Tropics: Diagrammatics of the New Structuralist Macro Critique." In W. Cline and S. Weintraub (eds.) Economic Stabilization in Developing Countries. Washington DC: The Brookings Institution, 1981. 


\section{Figure 1 : fall in exports}

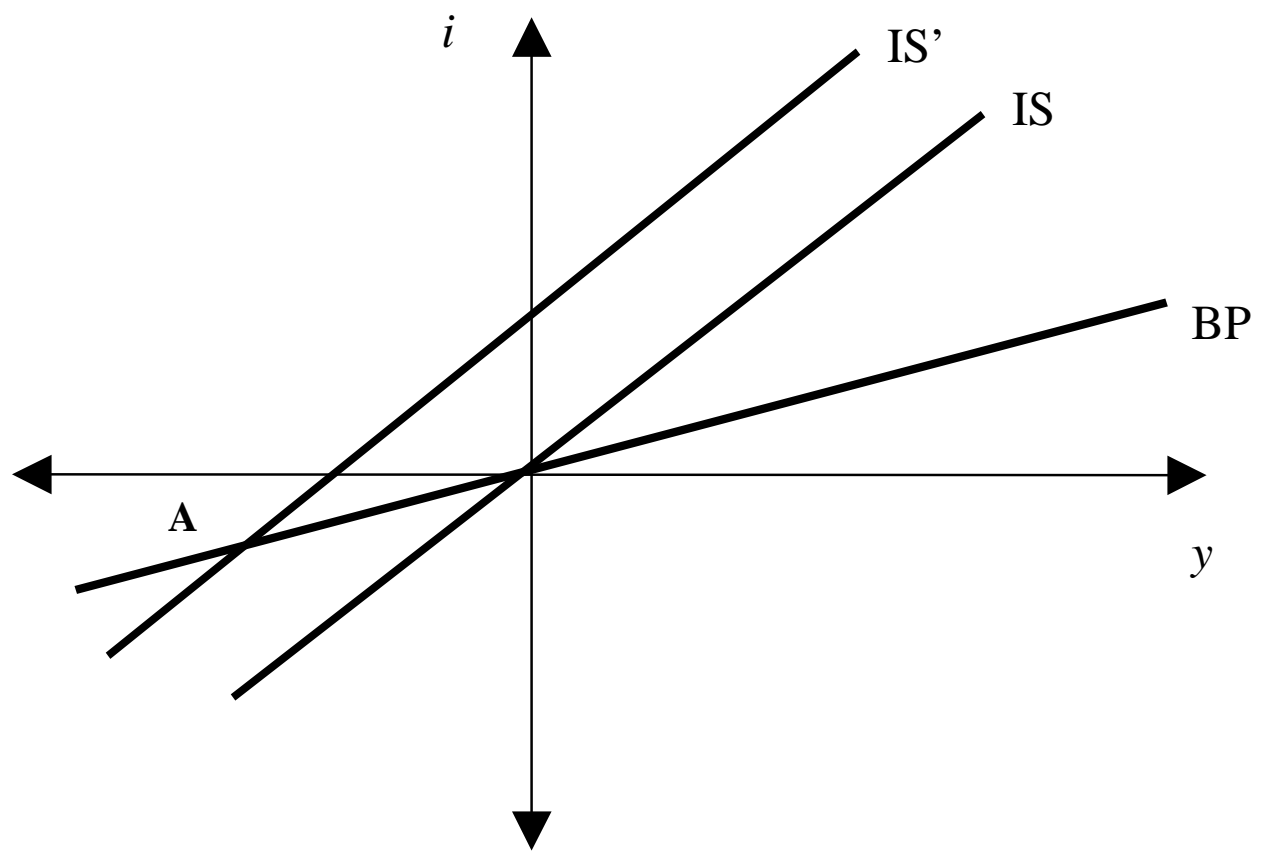


Figure 2: increase in the world interest rate

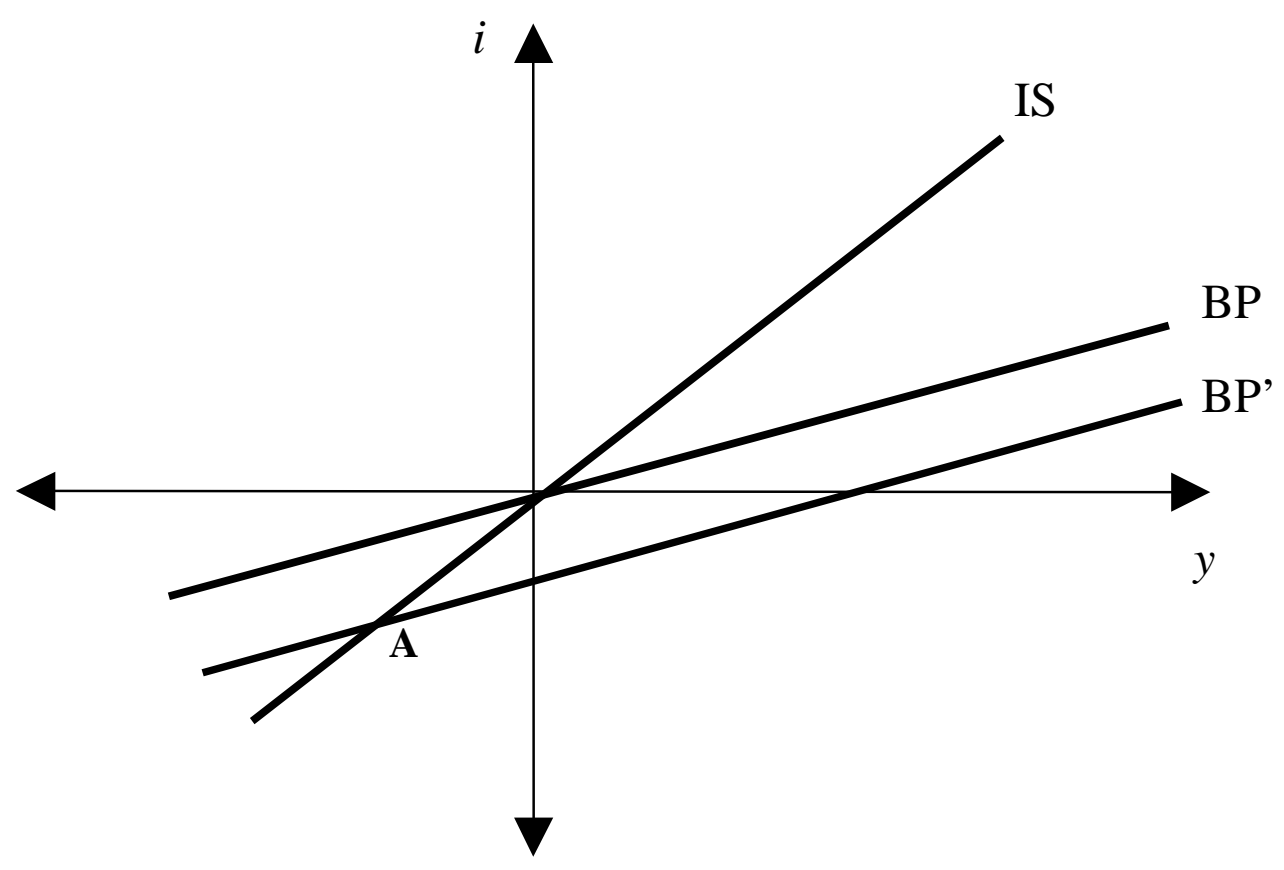




\section{Figure 3: devaluation in financially robust economy}

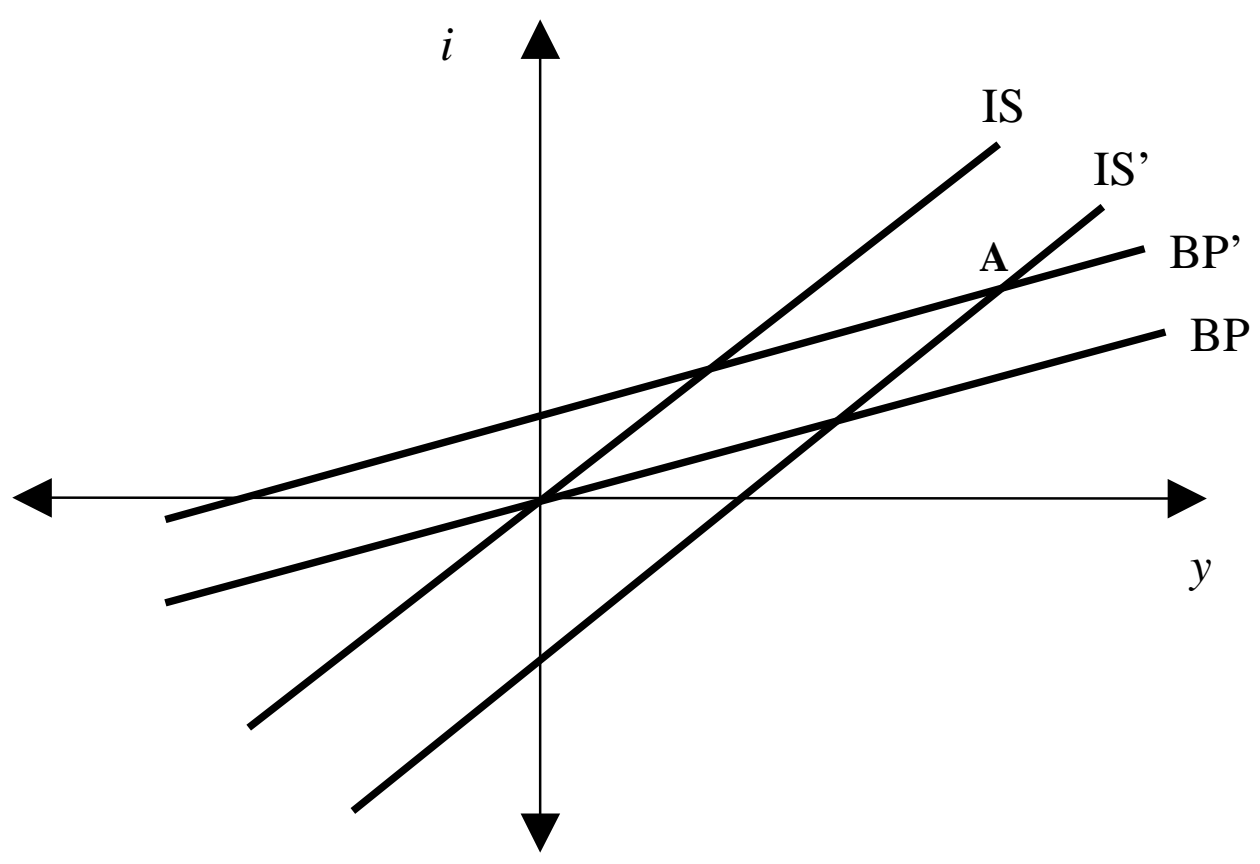




\section{Figure 4: devaluation in financially vulnerable economy}

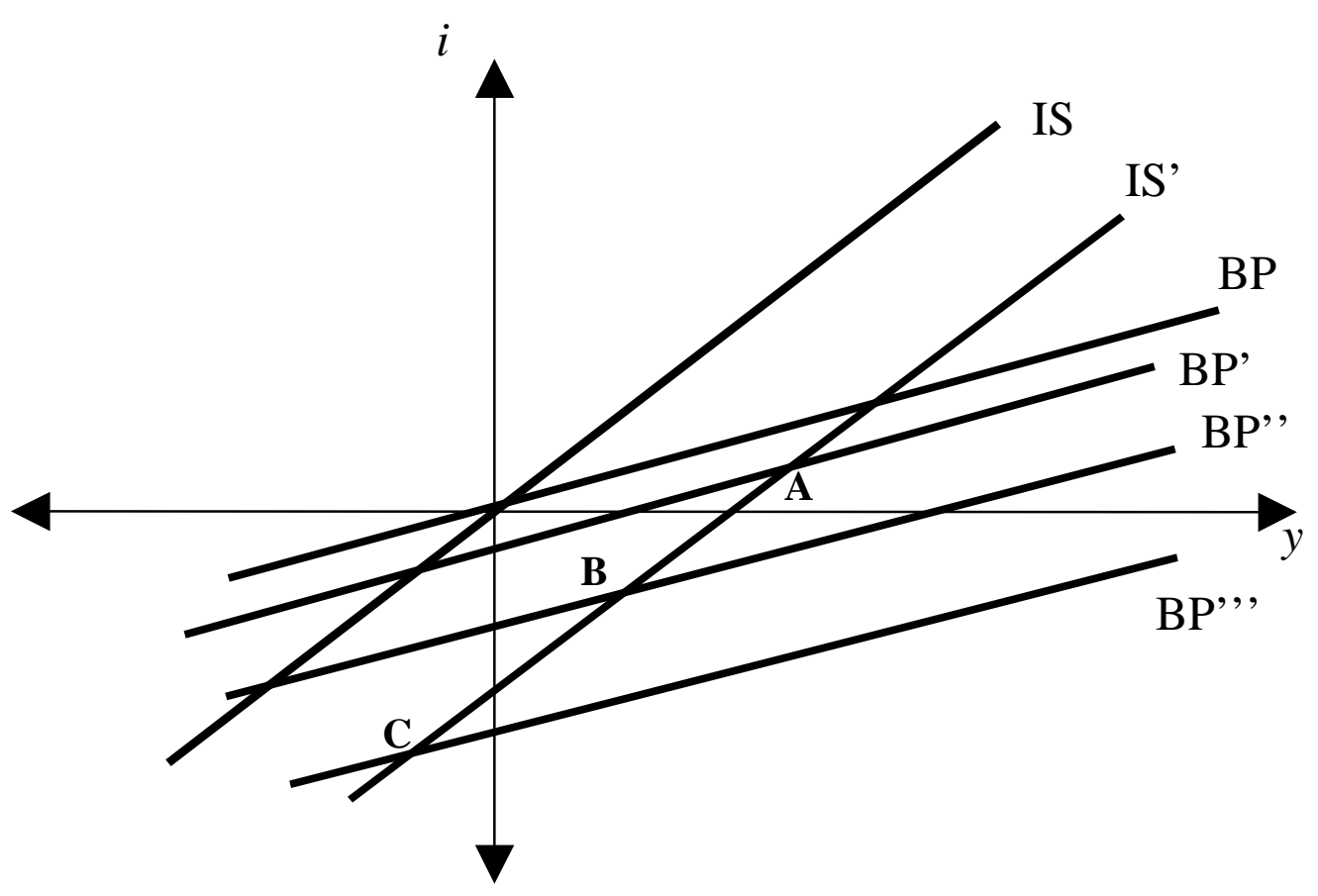

